\title{
A MAGYAR NYELV MURAVIDÉKI VÁLTOZATA AZ ÚJ ÉVEZREDBEN - AZ OKTATÁS ÉS A KUTATÁS KONTEXTUSÁBAN
}

\section{THE PREKMURJE VARIETY OF THE HUNGARIAN LANGUAGE IN THE NEW MILLENNIUM - IN THE CONTEXT OF EDUCATION AND RESEARCH}

\author{
Kolláth Anna \\ PhD, egyetemi tanár, Filozofska fakulteta Univerze v Mariboru/Maribori Egyetem Bölcsészettudományi Kar, Maribor, Szlovénia \\ anna.kollath@um.si
}

ÖSSZEFOGLALÁS

Köztudomású, hogy a magyar nyelv Közép-Európában speciális helyzetű: Trianon következményeként ma nyolc, egymással szomszédos országban él, Magyarországon, az egyetlen teljes központon kívül az ottani államnyelv árnyékában, különböző társadalmi és gazdasági körülmények között, más-más státuszban. A szlovéniai Muravidék hatezer fős őshonos magyar nemzeti közössége anyanyelvhasználatát, a közösségi (nyelvi) jogokat az ország alkotmánya minden szinten biztosítja, a territoriális kisebbség lakóhelyén, az ún. nemzetiségileg vegyesen lakott területen a magyar nyelv hivatalos státuszú, a szlovén államnyelvvel azonos rangú regionális hivatalos nyelv.

A tanulmány a muravidéki nyelvi helyzet legmeghatározóbb elemeinek bemutatására törekszik. Teszi ezt a közoktatás kontextusában, hiszen a szerző meggyőződése, hogy az anyanyelvi és az anyanyelvű oktatás a nyelvi megmaradás alapfeltétele. Rámutat a magyar nyelv iskolai jelenlétére, a standard és a helyi kontaktusváltozat egymás mellett élésére. Érinti azokat az innovációkat, amelyek az utóbbi tíz évben markánsan meghatározzák a hatvanéves kétnyelvű oktatás arculatát.

\section{ABSTRACT}

It is common knowledge that Hungarian language has a unique position in Central Europe: Due to the peace agreement of 1920 formally ending World War I it is present in eight neighbouring countries. In Hungary, which is the only complete centre, in the others it usually exists in the shadow of the state languages, respectively, under different social economic circumstances and in different statuses. The autochthonous ethnic Hungarian community of six thousand people in the Prekmurje region, Slovenia, the right of the community to use its language, the community (language) rights are enshrined in the Slovenian constitution at every level, Hungarian has the status of an official language (regional official language) at the residence of the territorial minority (an area with ethnically mixed population).

The study presents the key elements of the language situation in the Prekmurje region, and does so by placing the issue in the context of public education as we firmly believe that learning 
the mother tongue and education in the mother tongue are essential for the survival of the language. It highlights the presence of this non-dominant variation (rudimentary centre) of the Hungarian language in schools, the levels of teaching Hungarian and its linguistic presence in teaching various subjects. It also touches upon the innovations that have significantly shaped the path of bilingual education.

Kulcsszavak: Szlovénia, muravidéki magyarság, kétnyelvű oktatás, e-kompetenciák, Termini Magyar Nyelvi Kutatóhálózat, többközpontú nyelvek, additív szemlélet, környezetnyelv

Keywords: Slovenia, Hungarian ethnic minority in the Prekmurje region, bilingual education, e-competences, Termini - Hungarian Language Research Network, pluricentric languages, additive perspective in the education, language of the environment

\section{BEVEZETŐ GONDOLATOK: A MAGYAR NYELV ÉS KUTATÁSA AZ EZREDFORDULÓN}

Köztudomású, hogy a magyar nyelv Közép-Európában, a Kárpát-medencében speciális helyzetü. A több ok közül most elsősorban a trianoni negatív sorsesemény emelendő ki: az a tény, hogy Trianon következtében ma nyolc országban él: beszélőinek többsége Magyarországon, azaz az anyaországban, de rajta kívül még hét szomszédos országban: Erdélyben (Románia), a Felvidéken (Szlovákia), a Vajdaságban (Szerbia), Kárpátalján (Ukrajna) ${ }^{1}$, valamint a Muravidéken (Szlovénia), a Drávaszögben (Horvátország) és az Örvidéken (Ausztria) ${ }^{2}$, az ottani államnyelv árnyékában, különböző társadalmi és gazdsági körülmények között, más-más státuszban (Szilágyi, 2002). Az összmagyar nyelv léte, létezése és ennek megfelelően tudományos kutatása csak a rendszerváltás után (1989-től kezdve) indulhatott meg igazán - a Magyar Tudományos Akadémia Nyelvtudományi Intézetében a nyolcvanas évek közepétől kezdődő élőnyelvi kutatásokból kinőve, a korábbi szemlélet gyökeres megváltozásával. Kimondható ténnyé és gyakorlattá vált a valóság, miszerint a magyar nyelv határai nem esnek egybe az országhatárokkal, s a magyar nyelv nem csak a magyarországi magyar nyelvet jelenti. A fiatal magyar szociolingvistáknak köszönhetően - elsősorban a Kontra Miklós nevével fémjelzett Élőnyelvi Konferenciák hatására - megindult egy olyan folyamat a magyar nyelvtudományban, amely a külső régiók magyar nyelvhasználatának szociolingvisztikai elemzésére vállalkozott. A vállalkozás első sikerét a Kontra Miklós szerkesztette $A$ magyar nyelv a Kárpát-medencében a XX. század végén címủ sorozat darabjai jelentették (Csernicskó, 1998; Göncz, 1999;

\footnotetext{
${ }^{1}$ Ezt a négy magyarlakta területet ún. nagyrégióként tartja számon a magyar (társas)nyelvészet, hiszen viszonylag nagy (összefüggő) területen nagy létszámú magyar beszélőközösség él.

${ }^{2}$ Ezek a kisrégiók, amelyek mind területükben, mind a beszélöközösség létszámában sokkal kisebbek a nagyrégióknál.
} 
Lanstyák, 2000; Szépfalusi et al., 2012; Fancsaly et al., 2016). Az azonos szempontrendszeren nyugvó részletes elemzések, a kérdőíves és interjús gyüjtések eredményei egyrészt bekerültek az európai tudományos vérkeringésbe (Kontra, 2003), másrészt kijelölték az utat a továbblépéshez: megmutatták az anyaországbeli és a külső régiós magyar nyelv és nyelvhasználat különbségeit, illetve azonos vagy hasonló tendenciáit. A különbségek tudományos rendszerességgel való leírását napjainkban az MTA kiemelt támogatását élvező, 2013-ban alakult Termini Magyar Nyelvi Kutatóhálózat végzi (URL1), amelyben ma már mind a nyolc régió nyelvészei, szociolingvistái részt vesznek, s különbözö témákban dolgoznak a magyar nyelv határtalanitásának folyamatában. ${ }^{3}$ Ennek a gyökeres szemléletváltásnak a következményeként vetődött fel a magyar nyelv többközpontúságának gondolata is. Lanstyák István 1995-ös tanulmánya valósággal berobbant a magyar nyelvtudományba, nagy port kavarva szinte mind a mai napig (Lanstyák, 1995a). Az új „elmélet” szerint minden olyan nyelv többközpontú, amely egynél több országban használatos a fergusoni (E) funkcióban (az államigazgatás, az oktatás, az egyes szakmák, a tömegtájékoztatás, az egyházi szertartások, a kulturális élet, a tudományos kutatás területén). ${ }^{4}$ A többközpontú nyelveknek teljes (complete), részleges (partial) és kezdetleges (rudimental) központjai vannak. Ennek alapján a magyar is többközpontú nyelv. ${ }^{5}$ Egyetlen elsődleges és teljes központja Magyarország, de van négy részleges központja - a külső nagyrégiók, amelyek az adott változat státusza, az illető országban vagy régióban betöltött funkciója, standardizáltságának mértéke alapján különülnek

${ }^{3}$ Határtalanításon (detrianonizáció) azokat az elsősorban lexikológiai, lexikográfiai és korpusznyelvészeti munkálatokat értjük, amelyeknek az a céljuk, hogy a magyar nyelv szótárai, nyelvtanai, kézikönyvei ne csak a magyarországi magyar nyelvvel foglalkozzanak, hanem összmagyarrá váljanak. A magyar nyelvtudomány egyetemessége (összmagyarsága) azt jelenti, hogy az egyetemes magyar nyelvet tekinti kutatása tárgyának és leírása céljának, ebbe pedig szervesen beletartozik a határon túli magyar beszélőközösségek nyelvhasználata is. A témának ma már könvtárnyi szakirodalma van (lásd bővebben: Kolláth, 2005, 98-143. Lanstyák, 2005, 2006, 2008; Péntek, 2004 és passim).

${ }^{4}$ Prototipikus többközpontú nyelvek például az angol, a francia, a spanyol, a német, az arab, amelyek több országban használatosak államnyelvként. Többközpontúnak szokás tekinteni azokat a nyelveket is, amelyeknek csupán egyetlen országban van államnyelvi státuszuk, de a fent említett színtereken, illetőleg azok egy részén máshol is használatosak. Általában olyan őshonos kisebbségek nyelvei tartoznak ebbe a csoportba, melyeket egy-egy régióban a lakosság jelentős része beszél. Rudolf Muhr például a többközpontú nyelveket három csoportba sorolja: a köztes kategória az ún. Sprachen ungewissen plurizentrischen Status (többközpontúságukban bizonytalan státuszú nyelvek), s ide tartozónak véli (Európa nyelveit kategorizálva) a magyart is, együtt az albánnal, az örménnyel, az orosszal, a bosnyákkal (szerbbel) és a románnal, nationale Varietätnek, azaz nemzeti változatnak nevezve őket (Muhr, 2003). Az elnevezés problematikájáról (nemzeti változat) állami változat) lásd például Lanstyák, 1995a.

${ }^{5}$ Ennek meghatározásában elsősorban szociolingvisztikai, nyelvpolitikai és nyelvkörnyezettani kérdések játsszák a legfontosabb szerepet (Lanstyák, 1995b). 
el egymástól (Clyne, 1992; Lanstyák, 1996; Muhr, 1997, 2003; Kolláth, 2005, 77-79.). A három kisrégió kezdetleges központúsága ${ }^{6}$ még kérdéses, elsősorban a helyi magyar standard hiánya ${ }^{7}$ vagy hiányossága miatt (Bokor, 2001; Kolláth, 2005). Az ottani magyar nyelvváltozatok széles spektrumú kutatása, tudományos vizsgálata minden bizonnyal egy-egy lépéssel közelebb viszi a nyelvtudományt a (nyelvi) valósághoz.

\section{A MURAVIDÉKI MAGYAR NEMZETI KÖZÖSSÉG - DEMOGRÁFIA, NYELVI HELYZET}

2.1 A 2002. évi népszámlálás adatai szerint Szlovéniában 6243 magyar nemzetiségủ és 7713 magyar anyanyelvủ állampolgár él. ${ }^{8}$ A szlovén Statisztikai Hivatal adatai szerint 5212 magyar nemzetiségü és 6237 fö magyar anyanyelvü polgár él a kétnyelvü területen. A főként Ljubljanában, illetve Szlovénia nagyobb városaiban élő migráns magyar közösség létszáma tehát 1031 före tehető a nemzetiségi és 1476 före az anyanyelvi megoszlás szerint (a fővárosban és Muraszombatban kulturális egyesületeik is vannak). A magyar lakosság fogyása az 1991. évi adatokhoz viszonyítva magas: 2002-ben 22\%-kal kevesebben vallották magukat magyar nemzetiségünek, anyanyelvükként pedig 12\%-kal kevesebben jelölték meg a magyart, mint tizenegy évvel azelött. A csökkenés az utóbbi évek társadalmi-politikai, szociokulturális folyamatainak tudható be, benne az asszimiláció erősödését látják az elemzők. A muravidéki magyarok csúcsszervezete (Muravidéki Magyar Önkormányzati Nemzeti Közösség, MMÖNK) a 2011. évi cenzusban mindenképpen érvényesíteni szerette volna az ún. kettős vagy többes kötődés megjelölésének lehetőségét is (tárgyalások ennek megvalósít(hat)ásáról már a 2002-es népszámlálás előtt is folytak, de akkor nem sikerült a megvalósítás). A szándékot azonban 2011-ben is keresztülhúzta a megváltozott valóság: a regiszteralapúvá alakult népszámlálás nem tartalmazza ugyanis a nemzetiségi hovatartozás és a nyelvhasználat adatait. 2002 óta tehát nincsenek hivatalos adatok, csak becslések a szlovéniai magyarok számáról (Kovács, 2011a, 2011b).

\footnotetext{
${ }^{6}$ Kezdetleges központokról azokban az országokban/régiókban beszélhetünk, amelyekben, ha nincs is magyar nyelvű közigazgatás, de van egyfajta közélet, s vannak a standard nyelvváltozatot használó anyanyelvủ iskolák, az illető kisebbség újságokat ad ki, rendszeresen (még ha csekély terjedelemben is) rádióműsorokat sugároz, kulturális szervezeteket müködtet, s ezekben a nyelvhasználat standard jellegü (Lanstyák, 1995b).

${ }^{7}$ Ezt a szerepet általában a többségi nyelv (államnyelv) tölti be.

${ }^{8}$ A Kárpát-medencei külső régiókban - Horvátország és a Vajdaság kivételével - mindenütt többen vallják magukat magyar anyanyelvünek, mint ahányan magyar nemzetiségủnek (Gereben, 1998; Kocsis, 2003).
} 
2.2 A muravidéki magyar nemzeti közösség - a Tengermelléken élő olaszok közösségével együtt - autochton kisebbség Szlovéniában. ${ }^{9}$ Territoriális kisebbség, a Szlovén Köztársaság Alkotmánya által biztosított külön jogok az ún. nemzetiségileg vegyesen lakott területen (pontos kiterjedését a kétnyelvü települések statútumai rögzítik) a magyar lakosság számarányától függetlenül érvényesek. A magas fokú jogvédelem alapja a pozitív diszkrimináció (kisebbségi többletjog). A közösség az oktatás, a kultúra és a tájékoztatás terén, illetve az anyaországgal ápolt kapcsolataiban külön lehetőségekkel rendelkezik, s ezt az állam a költségvetésből támogatja (Göncz, 2006, 17-18.; Kolláth, 2005, 14-26.). A közösségnek képviselöje van a Szlovén Parlamentben, a képviselőnek a kisebbséget érintő kérdésekben vétójoga van.

A magyar nyelv a kétnyelvü területen a szlovén államnyelvvel egyenrangú, regionális hivatalos nyelv státusszal rendelkezik. A helynévtáblák, a feliratok kétnyelvủek. A magyar kisebbségnek van magyar nyelvủ rádiója (URL2), amely negyven különböző müsort sugározva 24 órán keresztül szól a hallgatókhoz; heti négy alkalommal jelentkezik a Hidak/Mostovi címü tévéadás (URL3). Az egyetlen hetilap a Népújság (URL4), valamint megjelennek különböző periodikái is. A közösségben élénk kulturális és tudományos élet folyik (van magyar nyelvü könyvkiadás), ezek szervezője a Magyar Nemzetiségi Müvelődési Intézet (URL5), illetve a Muravidéki Tudományos Társaság (URL6) (erröl bővebben: Kolláth-Gróf, 2013). A közösségnek olyan két(tan)nyelvü közoktatási modellje van, amely lehetővé teszi az anyanyelv megőrzése mellett az államnyelv magas szintủ elsajátítását is. A mind a többség, mind a kisebbség számára egyaránt kötelezö oktatásban mind a két nyelv tantárgy és tannyelv is egyben. Ez a reciprocitás a kisebbségi anyanyelv presztízsének emelésével is járna (a többi előny mellett), ha minden úgy müködne, ahogy azt 1959-ben kialakította és azóta folytonosan fejleszti, korszerüsíti a kisebbségi és a többségi oktatáspolitika. A szépen kidolgozott elmélet és a megvalósulás között azonban ellentét feszül a kisebbségi nyelvi létezés minden területén, $\mathrm{s}$ ez elsősorban a kisebbségi anyanyelv térvesztésében, életereje gyengülésében követhető nyomon.

Az elmélet és a gyakorlat egymáshoz közelítését szolgálja majd az ún. általános nemzetiségi törvény, amelyről a két autochton közösség parlamenti képviselöjének javaslatára már 2010 óta folynak a tárgyalások, a törvény megszövegezése, a végső változat kialakítása folyamatban van, elfogadása viszont még nem történt meg (ennek oka a tíz év alatti négy kormányváltásban is kereshető). A kerettör-

\footnotetext{
${ }^{9}$ Szlovénia etnikai sokszínüségét a két autochton nemzeti közösségen és az autochton roma etnikai csoporton kívül még huszonkét kisebbség reprezentálja. Az allochton kisebbséghez tartozók száma jóval több, mint az autochton kisebbségeké. Ez elég sokszor súrlódásokhoz vezet mind a kétnyelvü területen, mind pedig azon kívül (gyülöletbeszéd). A kisebbségek azonos jogokat szeretnének, egyre többször felmerül az autochtonitás legitimitásának kérdése.
} 
vény lényege az lenne, hogy megteremtse a törvények sok esetben átláthatatlan útvesztőjében a követhető rendet, biztosítsa a jogok érvényesítését, elsősorban megfelelő szankcionálási szabályok segítségével.

\section{KÉTNYELVŰ OKTATÁS}

3.1 A Muravidék általános iskoláiban 1959 óta, egyetlen középiskolájában pedig 1981 óta kétnyelvü oktatás folyik. ${ }^{10}$ A két nyelv - a többségi szlovén és a kisebbségi magyar - megőrzésének kétirányú/egyenrangú oktatási modellje (NećakLük, 1989, 11.; Kolláth, 2009, 42.) a kétnyelvü programok tipológiájában az erős kétnyelvü oktatás egyik fajtája (Baker, 1996; Garcia, 1997; Kontra, 2004). Kétirányúsága, egyenrangúsága elsősorban azt jelenti, hogy a két nyelv tanulásának folyamatában megszerzett alapvető nyelvi készségek lehetővé teszik a szaktantárgyak esetében a mindkét nyelven tanulást, ugyanakkor a nem nyelvi tantárgyak következetes kétnyelvüsége fejleszti a nyelvi, a szaknyelvi készségeket is, s nem csupán szakmai ismeretekkel gazdagítja a diákokat. Azt jelenti, hogy a szaktantárgyak kétnyelvüsége megalapozná és fejlesztené a szakmai kommunikációt, és nem szorítkozna csak arra, hogy az egyes tantárgyak oktatásában a legfontosabb terminus technikusok magyarul is bekerüljenek a füzetbe. Az egykor szépnek, hasznosnak, hatékonynak, a kisebbségi anyanyelvet annak használatában megőrizni képesnek, s az államnyelvet a lehető legmagasabb szinten elsajátíttatónak elképzelt oktatási modell tehát nem hozta meg a várt eredményeket. Az elmélet és a gyakorlat között egyre mélyül(t) a szakadék, a magasabb presztízsủ államnyelv az iskolában is színtereket alakított közel szlovén egynyelvűvé vagy legalábbis szlovén első nyelvűvé. Mind a többség, mind pedig a kisebbség tanulja ugyan továbbra is egymás nyelvét, ${ }^{11}$ minden diák tanulja a szaktantárgyakat egyazon órán belül - elvileg azonos időtartamban és mértékben - a saját és a másik nyelvén, kötelező jelleggel, de mégis elsősorban a magyar diákok válnak (funkcionális) kétnyelvüvé, a szlovén diákok kétnyelvüsége más mércével mérendő, és általában a valamennyit értés szintjén marad, s csak kevés esetben válik hasznos tudássá.

Ennek ellenére az oktatás szakemberei valamennyien egyetértenek abban, hogy a kisebbségi anyanyelvnek csak a kétnyelvü oktatásban van esélye a megmaradásra, anyanyelvi iskolákat, osztályokat már nem bírna el a kialakult nyelvi valóság (Bence, 2011; Bernjak, 2011; Bokor, 2001; Kolláth, 2009). A helyzeten csak és kizárólag a meglévő és (jól) müködő rendszeren belüli korrekciók tudnak

\footnotetext{
${ }^{10}$ A két oktatási szint közti huszonkét éves fáziskésés erősen befolyásol(hat)ta egy egész generáció identitását, a magyar nyelvhez és kultúrához füződő attitűdtartalmait.

${ }^{11}$ A kisebbségi magyar nyelv oktatását sok újítás segítette és segíti ma is, a tanulmányban ezek közül többröl is szó lesz.
} 
javítani. Éppen ezért mind az érintett oktatási intézmények, mind az oktatáspolitika mindent megtesz annak érdekében, hogy szakmai és anyagi lehetőségeket teremtsen az innovációkra. Ezekből az utóbbi tíz évben több is volt.

3.2 Megteremtődött például a magyar és a szlovén nyelv párhuzamos oktatása $(\mathrm{HOP})^{12}$ az első osztálytól kezdve, a szülőknek tehát nem kell dönteniük gyermekük iskolába kerülésekor, melyik nyelvet tanulja a gyermek anyanyelvként (magyarl vagy szlovén1), melyiket második nyelvként (magyar2, szlovén2). A program megvalósulása $A$ kétnyelvü iskolák predagógusainak e-kompetenciái/E-kompetence učiteljev $v$ dvojezičnih šolah (URL7) címü kutatási projektnek köszönhető. Kísérleti jelleggel indult a Lendvai 1. Számú Kétnyelvü Általános Iskolában a 2013/2014-es tanévben; sikerességének bizonyítéka, hogy azóta a Muravidék mind a négy általános iskolájában bevezették. A HOP-os csoportokba egyre több kisgyermek iratkozik, s ez azt (is) jelenti, hogy a kisebbségi anyanyelvủ csoportot egyre több magyar első nyelvủ kisdiák választja. Népszerüségének legfőbb oka, hogy vele párhuzamosan az államnyelv is tökéletesen megtanulható, s ez a muravidéki magyarok számára a kétnyelvủ létezés elengedhetetlen feltétele.

Napjainkban az iskolai osztálylétszámokat az uralkodó demográfiai trendek nagymértékben meghatározzák. A kéttannyelvü iskolákban is egyre kevesebb a gyerek, előfordul, hogy akár az egész intézmény, akár annak néhány tagozata kerül veszélybe, kérdésessé válik megmaradása. Ezért (is) fogadják örömmel az általános iskolák a Magyarországról érkező kisdiákokat, a középiskola pedig felveszi az egynyelvű iskolákból érkező, elsősorban a szakközépiskolai programokba jelentkező szlovén egynyelvü diákokat is. Világos, hogy az oktatás egész folyamatát az új helyzethez kell igazítani: más, új kompetenciákat is ki kell alakítani és viszonylag gyors ütemben fejleszteni, hiszen az új, egynyelvü diákoknak be kell kapcsolódniuk a kétnyelvű ismeretszerzésbe. Ezt szolgálja például a középiskolai magyaroktatásban bevezetett külső differenciáció. Ez azt jelenti, hogy az anyanyelvi magyar mellett a magyar mint második nyelv most már hivatalosan is szétbomlik: megmarad a környezetnyelvi csoport, de a magyar3 (vagy magyar2 KD/magyar2 külső differenciációval) ${ }^{13}$ az egynyelvü szlovén diákoknak szól, elvileg a magyarnak mint idegen nyelvnek az oktatását jelenti (erről bővebben: Kolláth, 2016).

12 HOP: Hkratno opismenjevanje v slovenščini in madžarščini v dvojezični osnovni šoli - Poskus hkratnega opismenjevanja, azaz párhuzamos írás- és olvasástanítás mindkét nyelven (a betűvetés párhuzamos tanítása mindkét nyelven).

13 A magyar2-es csoportok heterogenitása volt az egyik alapvető problematikája a muravidéki oktatáspolitika által elkészített 2010-es oktatásstratégiának: az itt elképzelt és vázolt külső differenciáció (a magyar2 KD, azaz a magyar mint idegen nyelv bevezetése) valósulhatott meg az E-projektben. 
3.3 A magyar mint környezetnyelv külső differenciációja mindenképpen sikertörténet a muravidéki kéttannyelvű középiskolai oktatásban. A diákok egyre biztosabb nyelvi készségekre tesznek szert, $\mathrm{s}$ ami nagyon fontos: pozitív irányban alakul nyelvi attitüdjük, ez pedig újra csak energiákat szabadít fel a magyar nyelv tanulására. Látják, sőt saját bőrükön tapasztalják a kétnyelvủ oktatás és ezzel a két nyelvben, két kultúrában élés pozitívumait, az élményeket, megtanulnak pozitívan élni a mássággal, ami napjainkban nem elhanyagolható szempont (Šantak, 2016, 52.). S a hatás-ellenhatás elve alapján a szlovén anyanyelvủek erősödő magyar nyelvi kompetenciája hatékonyabbá teszi a kétnyelvű oktatás egész folyamatát. ${ }^{14}$

Ez a nagyon fontos innováció egészséges és szükséges kompromisszum is egyben, amely a kisebbségi nyelv iskolai jelenlétének, ezzel presztízsének emelésén kívül biztosítja az intézményi megmaradást is.

3.4 A muravidéki kétnyelvű oktatási modell müködését több törvény és előírás szabályozza állami és lokális szinten, jogi háttere megnyugtatóan biztosítva van. A szlovén oktatási rendszer szerves részeként létezik, egynyelvü iskolák a kétnyelvü területen nincsenek. Az iskolák müködését - a Szlovén Köztársaság Alkotmánya alapján - az oktatási különjogok biztosítják (ZPIMVI, Zakon o posebnih pravicah italijanske in madžarske narodne skupnosti na področju vzgoje in izobraževanja/Törvény az olasz és a magyar nemzeti közösség külön jogairól az oktatás és a nevelés területén; URL8). Az oktatás folyamatában megmutatkozó, egyre többször és mind hangosabban artikulált anomália, miszerint a kétnyelvü oktatás hatékonyságát nagymértékben befolyásolja az a tény, hogy leendő óvodapedagógusai, tanítói és (nem magyar szakos) tanárai szlovén egynyelvủ egyetemi képzésben szereznek diplomát, ${ }^{15}$ arra késztette a muravidéki oktatáspolitikusokat, élükön Göncz László parlamenti képviselővel, hogy a 2001. május 6-án érvénybe lépett oktatási különtörvényt módosítsák, aktualizálják, kiegészítéseket, változtatásokat eszközöljenek néhány cikkelyben, biztosítva ezzel a két tannyelv

${ }^{14}$ A Maribori Egyetem Bölcsészettudományi Kara Magyar Nyelv és Irodalom Tanszéke (Oddelek za madžarski jezik in književnost Filozofske fakultete Univerze v Mariboru), Szlovénia egyetlen magyar nyelvű felsőoktatási intézete is nyomon követi a közoktatás reformjait, hiszen a tanár szakos hallgatók képzésében feltétlenül meg kell jelenniük azoknak a tartalmaknak, amelyeknek segítségével maximálisan meg tudnak majd felelni az új kihívásoknak. Mind a most készülő felsőoktatási törvény vagy az új nemzetiségi törvény, mind pedig a Bölcsészettudományi Kar magiszteri fokozatú programjainak éppen aktuális reakkreditációs folyamata lehetőséget ad arra, hogy a magyar nyelv és irodalom tanításának módszertanában nagyobb hangsúly essék például a magyar mint második és mint idegen nyelv oktatásának módszertanára.

${ }^{15}$ Szlovéniában másra nincs lehetőségük: magyar nyelvű oktatás egyedül a Maribori Egyetem BTK Magyar Nelv és Irodalom Tanszékén folyik, magyar alapszakos bölcsészdiploma és magyartanári magiszteri diploma szerezhető magyar nyelven. 
azonos rangját és értékét az oktatás folyamatában. A tanárok biztos, alapos nyelvtudása - szaktudásuk mellett - valóban biztosítéka lehetne a kétnyelvủ oktatás hatékonysága növekedésének. A módosított törvényt - közel hat évig tartó folyamatos tárgyalások, egyeztetések eredményeként - 2018. február 1-én fogadta el a Szlovén Parlament, hatályba pedig a Szlovén Közlönyben való megjelenésekor lépett (2018. február 21.). Kulcskérdése a 15. cikkely: a Közös Európai Nyelvi Referenciakeret kategóriáit használva pontosan meghatározza a tanárok (és más iskolai dolgozók) magyar nyelvi kompetenciájának szintjét (az előző törvény nem fogalmazott teljesen egyértelmúen, illetve a gyakorlati megvalósulásban voltak félreértelmezések). A nem pedagógus iskolai dolgozóktól B1 szintet vár el (küszöbszint), a szaktantárgyak tanáraitól B2-t (középszint), s haladó szintet (C1) követel meg a magyartanároktól, a magyar nyelvi csoportok tanáraitól, és azoktól az óvónőktől és tanítóktól, akik az egy személy - egy nyelv rendszerben a magyar nyelvért felelősek, azt oktatják (Kolláth, 2016, 2018). A Maribori Magyar Tanszék mindig is feladatának tartotta, hogy lehetőségeihez mérten részt vegyen az óvodapedagógusok, a tanítók és a nem magyar szakos tanárok magyar nyelvi és szakmódszertani képzésében is. Lektori órákat és szaknyelvi kurzusokat kínál fel az érdeklődő hallgatóknak. Az a cél, hogy a kétnyelvü közoktatásban végzett hallgatók (a magyar2 általános érettségi vizsga B2-es szintet ír elö) egyetemi éveik alatt elérjék a módosított oktatási törvényben megjelölt $\mathrm{C} 1$-es kompetenciaszintet, illetve minél közelebb kerüljenek hozzá, hogy - nyelveikben és nyelvi szakmaiságukban - megállják majd helyüket tanárként a kétnyelvü oktatásban. Csak bízni lehet abban, hogy a tanárjelöltek folyamatosan élni is fognak ezzel a nem mindennapi lehetőséggel (az első tapasztalatok nagyon biztatóak). Ez azért is nagyon fontos, mert tény, hogy a muravidéki magyar első nyelvủ diákok anyanyelve a helyi kontaktusváltozat, amely erősen (és archaikusan) nyelvjárásias, valamint a szlovénnal való együttélés következtében kontaktusos. A közmagyar standardot az iskolának kell(ene) megtanítania egy olyan nyelvi helyzetben, amelyben nem a magyar nyelv a domináns. Ez - ahogy a tények is mutatják nem egyszerü, de nem lehetetlen feladat.

\section{TUDOMÁNYOS KUTATÁS}

A muravidéki magyar nyelv, a magyar beszélöközösség vernakuláris (kontaktusnyelvjárási változat) kutatása az utóbbi két évtizedben egyre gazdagodott mind témájában, mind pedig módszerében. A legkedveltebb terület a kétnyelvü oktatás. Kutatják maguk az érintettek, a szlovéniai kisebbségi és többségi (oktatási) szakemberek, magyarországi és Kárpát-medencei kétnyelvűség-kutatók, nyelvészek, irodalmárok, szociológusok, politikusok. Az ELDIA nemzetközi kutatási projektben (URL9) készült szlovéniai esettanulmány (CSR) tartalmazza a 
2013-ig megjelent szakirodalmak jegyzékét (Kolláth-Gróf, 2014). A kutatások azt bizonyítják, hogy a muravidéki magyarok nyelvi helyzete rendkívül összetett, és ellentmondásoktól sem mentes. De tény, hogy a többnyelvűségnek és a többkultúrájúságnak van a legfontosabb szerepe a közösség életében, ez a lételeme, ez az életformája, amelyen alapvetően nem akar változtatni. A TERMINI Magyar Nyelvi Kutatóhálózat (URL1) vizsgálatainak témájául tekinti a magyar nyelv e nem domináns változatát a magyar-magyar online szótár folyamatos munkálataival, a kétnyelvü közoktatás hatékonyságának elemzésével és új témaként, a nyelvi problémák adatbázissá dolgozásával, a hallható kétnyelvüség mellett a látható kétnyelvüség kutatásával (nyelvi tájkép/Language Landscape). A kutatások középpontjában - a kezdetektől fogva - a kétnyelvủ oktatási modell áll. Ezen nincs mit csodálkozni, hiszen a közösségi kétnyelvüség intenzitását, a kisebbségi magyar nyelv megmaradásának, a helyi standard változat (ki)alakulásának folyamatát meghatározza a kétnyelvü oktatás, hiszen szlovénok és magyarok immár hatvan éve tanulják együtt egymás nyelvét, és tanulnak egymás nyelvén. Az egyik legújabb szlovén kutatási projekt a kétnyelvűséget a többnyelvüség kontextusában vizsgálja (JeŠt - Jeziki štejejo/A nyelvek számitanak; ESS-projekt, URL10), a másik pedig a kétnyelvủ oktatás hatékonyságára, a hivatali kétnyelvüség alakulásában betöltött szerepére teszi a hangsúlyt (Uresničevanje ciljev dvojezične vzgoje in izobraževanja na narodnostno mešanem območju v Prekmurju/A kétnyelvü oktatás céljainak megvalósulása a Muravidék nemzetiségileg vegyesen lakott területén - fele-fele arányban a Szlovén Köztársaság Tudományos Kutatásokért Felelős Intézete és Oktatási Minsztériuma, URL11). De feltétlenül említést érdemel a magyar és szlovén akadémiai intézetek, egyetemi tanszékek közös munkájával most készülő magyar-szlovén nagyszótár is. Óriási hiányt pótol, ezért (online) megjelenése - bízunk benne - nem várat sokat magára.

A muravidéki magyar nyelvváltozatok, a nyelvi helyzet kutatása elengedhetetlen feltétele a nyelvben és kultúrában való megmaradásnak. Különösen fontos az is, hogy a kutatások eredményei, a tanulságok visszakerüljenek abba a közegbe, amelyből vétettek, csak így lehetnek ugyanis hatékonyak az érintettek számára.

\section{5. ÖSSZEFOGLALÁS}

A muravidéki kétnyelvủ oktatás mindkét nemzeti közösségé: magyaroké és szlovéneké egyaránt, eredményei, hatékonysága és hiányosságai csak ebben a kontextusban értelmezhetők hitelesen. Minden jel arra mutat, hogy az érintettek és az illetékes döntéshozók kilencvenes években megindult élénk párbeszéde folytatódik. Látjuk: a kétnyelvű oktatás belső innovációjához szükséges stratégia csak akkor hoz eredményeket, ha azonos cél vezérli a feleket. Ez pedig nem lehet más, mint - a nyelvi sokszínúség támogatásaként - az anyanyelvi megmaradás a nyelvhasználat 
minden színterén. A magyar anyanyelv muravidéki oktatásában csak az additív és a többnyelvüségi szemlélet járulhat hozzá a sikerhez: a vernakuláris anyanyelvváltozatra kell ráépülnie a (helyi) standard változatnak (ezt az iskola tanítja meg a magyar első nyelvü diáknak, hiszen anyanyelvváltozata a helyi kontaktusnyelvjárás), kialakítva ezzel a kétnyelvủ beszélőben az anyanyelvi kettős- vagy többesnyelvüséget (Bernjak, 2011, 193.; Kolláth, 2009, 39-40. passim).

Tény, hogy a magyart leginkább a kisebbségnek kell használnia a kétnyelvü Muravidéken (Nećak-Lük, 2011, 123.). De az is kétségtelen, hogy a szlovén többség magyartudása megakadályozhatná a nyelvi színterek szlovén egynyelvűvé válását, életet önthetne a magyar nyelvü közélet megnyilvánulásaiba, s ennek fontosságát a kisebbségi nyelv megmaradásának folyamatában nem lehet elégszer hangsúlyozni. A gyakorlat azt mutatja, hogy a magyar nyelv iskolai előfordulása - az érintettek minden erőfeszítése ellenére - nem teljesen megnyugtató. A szlovén nyelv dominanciája egyértelmü, és ez meghatározza a diákok nyelvi identitásának erővonalait. A magyar nyelv elsősorban kontaktusváltozataiban él a diákok körében, $s$ leginkább szóban jelentkezik (természetesen a[z anyanyelvi] magyarórán más trendek uralkodnak). A nyelvhasználat új szinterein, a digitális kommunikációban viszont már írásban is megjelenik, általában vernakuláris változatában, legtöbbször fonetikusan írva (ezekben nyelvváltások és nyelvváltozatváltások is megfigyelhetők). A magyar nyelvi színterek bővülése mindenképpen hozzájárul az anyanyelvben maradáshoz a kétnyelvủ létben.

\section{IRODALOM}

Baker, C. (1996): Foundations of Bilingual Education and Bilingualism. Clevedon: Multilingual Matters, https://bit.ly/2r5Crh0

Bence L. (2011): A kétnyelvü oktatás története. In: Király M. J. (ed.): 50 éves a kétnyelvü oktatás a Muravidéken. Lendva: Magyar Nemzetiségi Tájékoztatási Intézet, 13-54.

Bernjak E. (2011): Az oktatás szerepe a kisebbségi nyelv megőrzésében. In: Király M. Jutka (ed.): 50 éves a kétnyelvü oktatás a Muravidéken. Lendva: Magyar Nemzetiségi Tájékoztatási Intézet, 192-207.

Bokor J. (2001): A magyar nyelv és használata a szlovéniai Muravidéken az ezredforduló küszöbén. Magyar Nyelv, 97, 1, 34-52. http://www.c3.hu/ magyarnyelv/01-1/bokor.htm

Clyne, M. (1992): German as a Pluricentric Language. In: Clyne, M. (ed.): Pluricentric Languages. Differing Norms in Different Nations. Berlin-New York: Mouton de Gruyter, 1-9.; 455-465.

Csernicskó I. (1998): A magyar nyelv Ukrajnában (Kárpátalján). Budapest: Osiris Kiadó-MTA Kisebbségkutató Mühely, http://real.mtak.hu/19610/1/AMagyarNyelvUkrajnaban1998.pdf

Fancsaly É. - Gúti E. - Kontra M. et al. (2016): A magyar nyelv Horvátországban. BudapestEszék: Gondolat Kiadó-Media Hungarica Mủvelődési és Tájékoztatási Intézet, http://real. mtak.hu/50401/

Garcia, O. (1997): Bilingual Education. In: Coulmas, F. (ed.): The Handbook of Sociolinguistics. Oxford-Cambridge: Blackwell, 405-420. 
Gereben F. (1998): Az anyanyelv az identitástudat szerkezetében. Regio, 2, 95-112. http://epa. uz.ua/00000/00036/00032/pdf/06.pdf

Göncz L. (1999): A magyar nyelv Jugoszláviában (Vajdaságban). Budapest-Újvidék: Osiris Kiadó-Forum Könyvkiadó-MTA Kisebbségkutató Műhely, http://real.mtak.hu/24410/

Göncz L. (2006): A muravidéki magyarság tegnap és ma. Pro Minoritate, Nyár-Ősz, 5-19.

Kocsis K. (2003): A Kárpát-medence változó etnikai arculata (1989-2002). Kisebbségkutatás, 12, 4, 706-714.

Kolláth A. (2005): Magyarul a Muravidéken. Maribor: ZORA, 39.

Kolláth A. (2009): Két nyelv és oktatás. In: Kolláth A. (szerk.): A muravidéki kétnyelvü oktatás fél évszázada. Bielsko-Biała-Budapest-Kansas-Maribor-Praha: ZORA, 68. 36-60.

Kolláth A. (2016): A magyar nyelv és oktatása Szlovéniában. THL2: a magyar nyelv és kultúra tanitásának szakfolyóirata, 1-2, 45-55. http://epa.oszk.hu/01400/01467/00014/pdf/EPA01467 th12 2016 01-02 045-055.pdf

Kolláth A. (2018): Szaknyelvi kommunikáció mint többlettantárgy a pedagógusképzésben. Muratáj: irodalmi, müvelödési, társadalomtudományi és kritikai folyóirat, 1-2, 210-216.

Kolláth A. - Gróf A. (2013): Hungarian in Slovenia. ELDIA Case-specific Report (Studies in European Language Diversity 28). Mainz: Research Consortium ELDIA: Northern European and Baltic Languages and Cultures (SNEB): Johannes Gutenberg-Universität, https://services. phaidra.univie.ac.at/api/object/o:356605/diss/Content/get

Kolláth A. - Gróf A. (2014): A szlovéniai magyar nyelv. ELDIA esettanulmány. (Studies in European Language Diversity, 28). Mainz: Research consortium ELDIA: Northern European and Baltic Languages and Cultures (SNEB): Johannes Gutenberg-Universität, cop. https://fedora. phaidra.univie.ac.at/fedora/get/o:356645/bdef:Content/get

Kontra M. (2003): Élőnyelvi kutatások határainkon belül és kívül. Magyar Tudomány, 4, 504-512. http://www.matud.iif.hu/03apr/kontra.html

Kontra M. (2004): Tannyelv, (felső)oktatás, nyelvpolitika. Fórum Társadalomtudományi Szemle, VI, 4, 25-42. http://epa.uz.ua/00000/00033/00019/pdf/szemle_2004_4_kontra.pdf

Kovács A. (2011a): Népszámlálás 2011 (1): Stagnál a lakosság száma a Muravidék magyarlakta vidékén a 2011-es népszámlálás adatai alapján. Népújság, 49. 8., 18-19. https://issuu.com/nepujsag/docs/49-11nepujsag

Kovács A. (2011b): Népszámlálás 2011 (2) - Muravidék: Mennyi magyar élt a Muravidéken 2011ben? Népújság, 2011. december 15., 18. https://issuu.com/nepujsag/docs/50-11nepujsag

Lanstyák I. (1995a): A nyelvek többközpontúságának néhány kérdéséröl. Magyar Nyelvőr, 119, 3 , 213-236. http://www.jamk.hu/ujforras/960603.htm

Lanstyák I. (1995b): A magyar nyelv központjai. Magyar Tudomány, 10, 1170-1185.

Lanstyák I. (1996): Gondolatok a nyelvek többközpontúságáról (Különös tekintettel a magyar nyelv Kárpát-medencei sorsára). Új Forrás, 6, 25-38. http://www.jamk.hu/ujforras/960603.htm

Lanstyák I. (2000): A magyar nyelv Szlovákiában. Budapest-Pozsony: Osiris Kiadó-Kalligram Könyvkiadó-MTA Kisebbségkutató Mühely, http://real.mtak.hu/24413/

Lanstyák I. (2005): Határtalanítás (a Magyar értelmező kéziszótár 2. kiadása után, 3. kiadása előtt). In: Mártonfi A. - Papp K. - Slíz M. (szerk.): 101 irás Pusztai Ferenc tiszteletére. Budapest: Argumentum Kiadó, 179-186. https://bit.ly/2Plmb3g

Lanstyák I. (2008): A magyar szókészlet szétfejlődése 1918 után. Fedinec Cs. (ed.): Értékek és dimenziók a magyarságkutatásban. Budapest: MTA Magyar Tudományosság Külföldön Elnöki Bizottság, 118-135. https://mta.hu/data/dokumentumok/magyar_tudomanyossag_kulfoldon/Ertekek-dimenziok.pdf

Muhr, R. (1997): Zur Terminologie und Methode der Beschreibung plurizentrischen Sprachen und deren Varietäten am Beispiel des Deutschen. In: Muhr, R. - Schrodt, R. (Hrsg.): Österrei- 
chisches Deutsch und andere nationale Varietäten plurizentrischer Sprachen in Europa. Wien: Verlag Hölder-Pichler Tempsky, 40-66. https://bit.ly/33PylrB

Muhr, R. (2003). Die plurizentrischen Sprachen Europas - Ein Überblick. In: Gugenberger, E. - Blumberg, M. (Hrsg.): Vielsprachiges Europa. Zur Situation der regionalen Sprachen von der iberischen Halbinsel bis zum Kaukasus. (Bd.2 Österreichisches Deutsch - Sprache der Gegenwart) Frankfurt u.a.: Peter Lang Verlag, 191-233. http://www.info.oedeutsch.at/OEDTBIB/090-Muhr-2003-plurizentrische\%20Sprachen\%20Europas.pdf

Nećak-Lük, A. (1989): Vzgoja in izobraževanja v večjezičnih okoljih. Ljubljana: Pedagoški inštitut pri Univerzi Edvarda Kardelja v Ljubljani

Nećak-Lük, A. (2011): Tény, hogy a magyar nyelvet elsősorban a kisebbségnek kell használnia. In: Király M. J. (ed.): 50 éves a kétnyelvü oktatás a Muravidéken. Lendva: Magyar Nemzetiségi Tájékoztatási Intézet, 120-125.

Péntek J. (2004): A magyar nyelv szótárai, nyelvtanai, kézikönyvei és a határon túli magyar nyelvváltozatok. Az MTA határon túli kutatóállomásainak feladatait is ellátó nyelvi irodák állásfoglalása. Magyar Tudomány, 7, 724-726. www.matud.iif.hu/04jul/008.html

Šantak, B. (2016): A magyar mint második nyelv tanitásának helyzete és lehetöségei a Lendvai Kétnyelvü Középiskolában. Záró szemináriumi dolgozat. Maribor

Szépfalusi I. - Vörös O. - Beregszászi A. et al. (2012): A magyar nyelv Ausztriában és Szlovéniában. Budapest-Alsóőr-Lendva: Gondolat Kiadó-Imre Samu Nyelvi Intézet-Magyar Nemzetiségi Müvelődési Intézet, http://real.mtak.hu/22493/

Szilágyi N. S. (2002). A magyar nyelv a Magyarországgal szomszédos országokban. Előadás az MTA 2002. évi akadémiai közgyülésének keretében rendezett tudományos ülésszakon, 2002. május 2-án, Budapesten

Varga P. (2010): Átfogó nemzetiségi törvény. Népújság, 54, 44, $2-3$.

URL1: http://termini.nytud.hu

URL2: https://www.rtvslo.si/mmr/

URL3: https://www.rtvslo.si/hidak/

URL4: https://nepujsag.net/

URL5: http://www.mnmi-zkmn.si/

URL6: https://mta.hu/kulhoni_magyar_tudomanyos_muhelyek?WorkshopId=4138

URL7: http://www.e-kompetencia.si

URL8: http://pisrs.si/Pis.web/pregledPredpisa?id=ZAKO2611

URL9: eldia-project.org

URL10: https://www.jeziki-stejejo.si/

URL11: http://www.inv.si/Dokumenti/dokumenti.aspx?iddoc=943\&idmenu1=19\&lang=slo 